\title{
Effect of high hydrostatic pressure treatment on quality characteristics of squid 'Sikhae' prepared with barley flour during storage
}

\author{
Jae Hun Yang, Na-Young Lee* \\ Department of Food Science and Biotechnology, Kunsan National University, Gunsan 54150, Korea
}

\section{보리를 이용한 오징어 식해의 초고압처리에 의한 품질특성 변화}

\author{
양재훈 · 이나영* \\ 군산대학교 식품생명공학과
}

\begin{abstract}
The changes in the quality of squid 'Sikhae' prepared with barley flour by high hydrostatic pressure processing (HHP) were investigated. The $\mathrm{pH}$ and amino nitrogen content (Amino-N) of the squid 'Sikhae' prepared with barley were 6.77 and $0.18 \%$, respectively, and those on the 15 day of storage were 4.79 and $0.31 \%$, respectively. The volatile basic nitrogen (VBN) content of the squid 'Sikhae' prepared with barley flour was $60.18 \mathrm{mg} \%$ in the untreated sample and $20.53 \mathrm{mg} \%$ in the HHP-processed sample on the 10 day of storage. The $L^{*}$ value of the 'Sikhae' prepared with barley flour was found to be higher than that with millet. The total number of bacteria in the squid 'Sikhae' prepared with barley flour was 8.26 CFU/g in the untreated sample and 5.90 CFU/g in the HHP-processed sample on the 5 day of storage. The change in the number of lactic acid bacteria according to the storage period showed the highest value of $9.36 \mathrm{log}$ CFU/g on the 15 day of storage in the HHP-processed sample of the squid 'Sikhae' prepared with barley. Therefore, HHP processing of the low-salt fermented squid 'Sikhae' prepared with barley positively affected quality with increasing storage period.
\end{abstract}

Key words : Sikhae, fermented sea food, barley, HHP

서 론

수산발효식품은 어패류에 소금을 첨가하여 부패를 억제하 면서 자가소화 및 미생물의 작용에 의해 성분이 분해되고 숙 성되어 제조되는 발효식품이다(Kim 등, 2007). 수산발효식품 은 제조시 첨가되는 소금함량에 따라 고염도( $20 \%$ 이상), 저 염도(6-18\%) 및 무염도 식품으로 분류된다(Lee, 1989). 또한 어패류에 염장을 통해 제조되는 식품으로, 발효원리에 따라 젓갈류와 식해류로 구분이 된다(Park 등, 2017; Suh, 1987).

식해는 어패류의 주원료와 곡류를 포함한 무, 엿기름, 생 강, 고춧가루, 마늘 및 소금 등의 부원료로부터 유래되는 미
생물과 자가 효소에 의해 발효되는 어육발효식품이다 $(\mathrm{Kim}$ 등, 1994c). 소금함량이 6-8\% 정도 첨가되어 제조되는 저염 수산식품으로, 젖산 발효된 수산어육제품으로 분류된다(Lee, 1997). 수산발효식품인 젓갈류와 대조적으로 부원료로 첨가 되는 곡류는 식해의 숙성에 관여한다(Kim 등, 1994d). 식해 제조에 첨가되는 주요 곡류로는 조나 쌀 등을 이용하거나 또 는 이를 혼합하여 제조한다(Cho와 Kim, 2012; Han 등, 2012; Jeong 등, 2015; Kim 등, 2012; Kim 등 2013; Lee, 1997; Lee 등, 1996).

보리(Hordeum vulgare L.)는 주요 곡류자원 중의 하나로서 곡립의 구성 성분에 따라 찰성(waxy), 메성(normal), 고아밀로

*Corresponding author. E-mail : nylee@kunsan.ac.kr, Phone :+82-63-469-1826, Fax : +82-63-469-7448

Received 19 January 2021; Revised 04 March 2021; Accepted 19 March 2021.

Copyright (c) The Korean Society of Food Preservation.

This is an Open Access article distributed under the terms of the Creative Commons Attribution Non-Commercial License (http://creativecommons.org/licenses/by-nc/4.0) which permits unrestricted non-commercial use, distribution, and reproduction in any medium, provided the original work is properly cited. 
오즈 전분, 고라이신 함유, 고 $\beta$-glucan 함유, proanthocyanidinfree 형태로 분류된다(Baik과 Ullrich, 2008). 보리에는 arabinoxylan, $\beta$-glucan, oligosaccharides, tocols(tocopherols 와 tocotrienols)와 폴리페놀과 같은 생리활성 물질이 함유되 어 있으며(Baik과 Ullrich, 2008; Martínez 등, 2018; Sharma 와 Gujral, 2010), 보리에 포함된 수용성 식이섬유인 $\beta$-glucan 은 혈중 콜레스테롤을 낮추는 기능을 가진다고 보고되고 있 다(Ames와 Rhymer, 2008; Baik과 Ullrich, 2008). 찰보리는 수용성 및 불용성 식이 섬유의 급원으로, 식이섬유는 콜레스 테롤 및 혈당의 수치를 낮추는 역할을 한다(Pejcz 등, 2017). 또한, 찰성 보리는 단백질 및 $\beta$-glucan 등과 같은 성분을 함 유하며, 식품에 물리적 성질을 부여한다(Jeong 등, 2013).

초고압(high hydrostatic pressure)처리 기술은 비가열 처리 가공기술의 중의 하나로서 식품에 압력 매체를 이용하여 압 력을 작용시키는 기술이다(Lee 등, 2011; Park 등, 2010). 초 고압 처리 공정의 주요 장점 중 하나는 미생물 및 효소의 불 활성화를 통한 식품 안전성 향상 및 유통 기한 연장이다(Koo 등, 2007; Rendueles 등, 2011). 이러한 초고압 처리는 식품 분자구조내의 소수성 결합과 같은 비공유결합에 영향을 미치 며, 식품의 향미, 색, 영양성분 및 Maillard reaction과 연관된 열처리에서 유발되는 화학적 변화를 최소화한다(Koo 등, 2007; Park 등, 2010). 그러나 기존 식해 관련 연구에서 곡물 자원 대체나 초고압 기술적용과 관련한 연구는 매우 제한적 이다. 따라서 본 연구에서는 식해 제조시 사용되던 곡물자원 을 찰보리로 대체하여 오징어 식해를 제조하고, 초고압처리 기술을 적용하여 저장기간에 따른 식해의 품질 변화를 알아 보고자 한다.

\section{재료 및 방법}

\section{실험 재료}

본 연구의 식해 제조에 사용한 오징어(Todarodes pacificus, Mokpo, Korea)는 2019년에 어획된 것을 냉동상태로 구입하 여 사용하였고, 곡류로는 전라북도 군산지역에서 2019년도 에 생산된 차조(Saeng geum deul, Kunsan, Korea)와 흰찰쌀 보리(Saeng geum deul)를 구입하여 사용하였으며, 정제염 (Sempio, Seoul, Korea), 고춧가루(Bukim, Buan, Korea), 마 늘(Korea) 및 생강(Korea)은 각각 군산시 소재 마트에서 구 입하여 사용하였다.

\section{식해 제조 및 초고압 처리}

오징어 식해의 제조를 위해 냉동 저장된 오징어를 $4^{\circ} \mathrm{C}$ 에서 해동한 후 귀, 내장, 다리를 제거하고 몸통만을 폭 $1 \mathrm{~cm}$ 간격 으로 썰어 준비하였다. 오징어 식해 제조시 배합비는 Park
(2012)의 방법을 이용하여 제조하였으며, 어육 중량당 곡류 밥 20\%(조 및 보리 각각 $20 \%$ ), 고춧가루 5\%, 마늘 5\%, 생강 $3 \%$, 정제염 $5 \%$ 를 혼합하여 제조하였다. 곡류는 세척하여 곡 립을 호화한 후 믹서기(Blixer 4, Robot Coupe, Burgundy, France)를 이용하여 2,000 rpm의 속도로 호화된 조의 경우는 1 분, 호화된 찰보리는 3 분 동안 각각 분쇄하여 실험에 사용하 였으며, 제조된 식해는 진공필름을 이용하여 진공 포장하였 다. 초고압처리는 등방정수압성형기(ISA-CIP-S30-200, Ilshin Autoclave Co., Dajeon, Korea)를 이용하여 $24^{\circ} \mathrm{C}$ 에서 3,000 $\mathrm{kg} / \mathrm{cm}^{2}$ 의 압력을 20 분 동안 가하여 실시하였다. 초고압 처리 된 식해는 용기에 담아 $10^{\circ} \mathrm{C}$ 에서 보관하며 실험에 사용하였다.

\section{$\mathrm{pH}$, 아미노태질소(amino-N) 및 휘발성 염기질소(volatile basic nitrogen, $\mathrm{VBN}$ ) 함량 분석}

$\mathrm{pH}$ 는 시료 $2 \mathrm{~g}$ 을 마쇄하고 증류수로 50 배 희석한 후 원심 분리기(Ha-1000, Hanil Science Industrial Co., Ltd., Incheon, Korea)를 이용하여 $2,000 \mathrm{rpm}$ 에서 15 분 동안 원심분리하였 다. 분리한 상층액을 여과지(No.2, Advantec Toyo Kaisha, Ltd., Tokyo, Japan)로 여과한 후 pH meter(Ion S220, Mettler toledo, Schwerzenbach, Switzerland)를 이용하여 측정하였다.

아미노태질소(amino-N) 분석은 Park(2012) 및 Koo(2015) 의 방법을 이용하여 Formol 적정법으로 분석하였다. 시료 2 $\mathrm{g}$ 에 증류수 $50 \mathrm{~mL}$ 를 가하여 균질화하여 $100 \mathrm{~mL}$ 로 정용한 후 여과하였다. 여과한 여액 $25 \mathrm{~mL}$ 를 취해 $0.05 \mathrm{~N} \mathrm{NaOH}$ 용액으로 $\mathrm{pH}$ 를 $8.5 \pm 0.03$ 이 되도록 조정 후 중성 포르말린용 액 $20 \mathrm{~mL}$ 를 가하고, 다시 $\mathrm{pH} 8.5 \pm 0.03$ 이 되도록 $0.05 \mathrm{~N}$ $\mathrm{NaOH}$ 용액으로 적정한 후 그 소비량 $(\mathrm{mL})$ 을 계산하여 함량 (\%)으로 나타내었다.

휘발성 염기질소량(volatile basic nitrogen, $\mathrm{VBN}$ )은 식품공 전(KFDA, 2018)의 방법을 이용하여 분석하였다. 마쇄한 시 료 $10 \mathrm{~g}$ 에 증류수 $15 \mathrm{~mL}$ 를 혼합하여 30 분간 교반한 후, $10 \%$ trichloroacetic acid(TCA) 용액 $10 \mathrm{~mL}$ 를 넣어 $100 \mathrm{~mL}$ 로 정 용하였다. 정용된 용액은 원심분리기를 이용하여 $2,000 \mathrm{rpm}$ 에서 10 분 동안 원심분리한 후 상층액을 여과지로 여과하여 실험에 사용하였다. Conway unit 외실에는 시료 $1 \mathrm{~mL}$ 및 포 화 $\mathrm{K}_{2} \mathrm{CO}_{3} 1 \mathrm{~mL}$, 내실에는 $0.01 \mathrm{~N} \mathrm{H}_{2} \mathrm{SO}_{4}$ 용액 $1 \mathrm{~mL}$ 및 Brunswik 지시약 $10 \mu \mathrm{L}$ 를 각각 넣고 $25^{\circ} \mathrm{C}$ 에서 1 시간 동안 반응한 다음, $0.01 \mathrm{~N} \mathrm{NaOH}$ 로 적정하여 휘발성 염기질소량 $(\mathrm{mg} \%)$ 을 산출하였다.

\section{색도 분석}

색도는 색차계(CM-5, Konica Minolta Inc., Tokyo, Japan) 를 사용하여 명도( $\mathrm{L}^{*}$, lightness), 적색도( $\mathrm{a}^{*}$, redness) 및 황색 도(b*, yellowness)를 측정하였다. 색도분석에 사용된 표준백 
판의 $\mathrm{L}^{*}$ 값은 $97.91, \mathrm{a}^{*}$ 값은 $-0.27, \mathrm{~b}^{*}$ 값은 -0.23 이었다. 모 든 시료는 3 회 반복 측정하여 평균값으로 나타내었다.

\section{미생물 균수 측정}

식해의 총균수, 젖산균, 대장균군은 식품공전(KFDA, 2018) 의 방법을 이용하여 분석하였다. 미생물 분석을 위해 시료 10 $\mathrm{g}$ 에 멸균식염수 $90 \mathrm{~mL}$ 를 넣고 bagmixer(Model 400, Interscience, Saint-Nom-la-Bretechem, France)를 이용하여 1 분 30 초 동안 균질화하였다. 균질된 시료는 10 진 희석법으로 희석한 후 희석액 $1 \mathrm{~mL}$ 를 멸균 petri dish에 분주한 후 멸균 된 배지와 혼합하였다. 총균수는 표준평판법을 이용하여 plate count agar(Difco Laboratories, Sparks, MD, USA) 배 지를 사용하여 $35^{\circ} \mathrm{C}$ 에서 48 시간 배양하였으며, 젖산균은 유 산균수 측정방법을 이용하여 lactobacilli MRS agar(Difco Laboratories) 배지를 사용하여 $37^{\circ} \mathrm{C}$ 에서 48 시간 배양하였다. 대장균군은 desoxycholate Lactose agar(Difco Laboratories) 를 사용하여 $35^{\circ} \mathrm{C}$ 에서 24 시간 배양하였다. 배양한 후 생성된 집락수를 계수하였으며, 계수된 균수는 $\log \mathrm{CFU}$ (colony forming unit $/ \mathrm{g}$ 으로 나타내었다.

\section{통계분석}

모든 실험은 3 회 이상 반복하여 실험하였으며, 결과는 평 균과 표준편차로 나타내었다. 분석한 결과에 대한 통계적인 유의성 검정은 Statistical Packages for Social Science(SPSS, Chicago, IL, USA)를 이용하여 Duncan's multiple range test 로 유의수준 $5 \%$ 이내 $(\mathrm{p}<0.05)$ 에서 각 평균값에 대한 유의적 차이를 분석하였다.

\section{결과 및 고찰}

\section{$\mathrm{pH}$, 아미노질소 및 휘발성 염기성 질소 변화}

보리를 첨가하여 제조된 오징어 식해의 $\mathrm{pH}$ 변화는 Table
1 과 같다. 조를 첨가하여 제조된 오징어식해(NM)와 보리를 첨가하여 제조된 오징어식해(NB)의 숙성초기 $\mathrm{pH}$ 는 각각 6.71 및 6.77 로 나타났으며, 저장기간에 따라 감소하는 경향 을 나타냈다. 숙성 30 일에 $\mathrm{NM}$ 과 $\mathrm{NB}$ 의 $\mathrm{pH}$ 는 각각 4.60 및 4.57로 나타났으며, 저장기간 동안 보리를 첨가하여 제조된 시료의 $\mathrm{pH}$ 가 조를 첨가하여 제조된 식해보다 낮은 $\mathrm{pH}$ 를 나 타냈다. 조를 첨가하여 식해 제조 후 초고압 처리한 시료 (HM)와 보리를 첨가하여 식해 제조 후 초고압 처리 시료 $(\mathrm{HB})$ 의 $\mathrm{pH}$ 도 초기에 각각 6.73 및 6.78 을 나타내었으며, 저 장 25 일에 $\mathrm{HM}$ 및 $\mathrm{HB}$ 의 $\mathrm{pH}$ 는 각각 4.68 및 4.62 를 나타냈 다. 조를 첨가하여 제조된 식해의 경우 저장 15 일에서 25 일 에 초고압 처리구는 비처리구에 비해 낮은 $\mathrm{pH}$ 를 나타내었다. 그러나 보리를 이용하여 제조된 식해의 경우, 저장기간 동안 초고압 처리구는 초고압 비처리구에 비해 높은 $\mathrm{pH}$ 를 나타냈 다. Lee 등(1996)은 오징어 식해의 $\mathrm{pH}$ 는 $10^{\circ} \mathrm{C}$ 에서 숙성했을 경우 숙성기간이 지남에 따라 감소하였으며, 수분함량이 높 을수록 $\mathrm{pH}$ 저하가 급격히 이루어지는 경향을 나타낸다고 보 고하였다. 또한, Kim 등(1994a)은 오징어 식해의 저장 중 $\mathrm{pH}$ 의 감소는 식해 제조 시 첨가되는 곡류나 저농도의 식염함량 에 의한 미생물의 활성 증가로 유기산이 많이 생성되는 것이 원인이라고 보고하였다.

조를 첨가하여 제조된 오징어식해(NM)와 보리를 첨가하 여 제조된 오징어식해(NB)의 초기 아미노질소 함량은 각각 $0.18 \%$ 를 나타내었다(Table 2). 보리 첨가 및 초고압 처리에 의한 식해의 아미노태 질소 함량 변화는 저장 10 일에 유의적 차이를 보였다. $\mathrm{NB}$ 및 $\mathrm{HB}$ 시료의 경우, 저장 10 일째에 아미 노태 질소 함량은 각각 $0.25 \%$ 및 $0.22 \%$ 를 나타내었으며, 저 장 30 일에는 $0.43 \%$ 및 $0.36 \%$ 를 나타내었다. 초고압 처리된 식해의 아미노태질소 함량 변화는 초고압 무처리구와 비교시 저장 10 일 이후에는 낮은 함량을 나타내었다. Lim 등(2000) 은 초고압 처리한 멸치젓의 아미노태질소 함량은 $200 \mathrm{MPa}$ 및 $300 \mathrm{MPa}$ 에서는 큰 변화가 없었으나, 그 이상의 압력에서

Table 1. Changes in pH of squid 'Sikhae' made with barley flour by high hydrostatic pressure treatment during storage at $10^{\circ} \mathrm{C}$

\begin{tabular}{cccccccc}
\hline & \multicolumn{5}{c}{ Storage period (days) } \\
\cline { 2 - 7 } Sample $^{1)}$ & 0 & 5 & 10 & 15 & 20 & 25 \\
\hline $\mathrm{NM}$ & $6.71 \pm 0.02^{\mathrm{Ba} 2)}$ & $6.04 \pm 0.04^{\mathrm{Bb}}$ & $5.50 \pm 0.01^{\mathrm{Cc}}$ & $5.08 \pm 0.01^{\mathrm{Ad}}$ & $4.96 \pm 0.00^{\mathrm{Ae}}$ & $4.74 \pm 0.01^{\mathrm{Af}}$ & $4.60 \pm 0.01^{\mathrm{Bg}}$ \\
$\mathrm{NB}$ & $6.77 \pm 0.00^{\mathrm{Aa}}$ & $5.75 \pm 0.02^{\mathrm{Cb}}$ & $5.21 \pm 0.01^{\mathrm{Dc}}$ & $4.79 \pm 0.01^{\mathrm{Dd}}$ & $4.67 \pm 0.01^{\mathrm{De}}$ & $4.60 \pm 0.01^{\mathrm{Df}}$ & $4.57 \pm 0.01^{\mathrm{Cg}}$ \\
$\mathrm{HM}$ & $6.73 \pm 0.01^{\mathrm{Bb}}$ & $6.83 \pm 0.00^{\mathrm{Aa}}$ & $5.62 \pm 0.06^{\mathrm{Bc}}$ & $4.95 \pm 0.01^{\mathrm{Bd}}$ & $4.80 \pm 0.01^{\mathrm{Be}}$ & $4.68 \pm 0.01^{\mathrm{Bf}}$ & $4.63 \pm 0.01^{\mathrm{Ag}}$ \\
$\mathrm{HB}$ & $6.78 \pm 0.00^{\mathrm{Ab}}$ & $6.87 \pm 0.01^{\mathrm{Aa}}$ & $5.82 \pm 0.04^{\mathrm{Ac}}$ & $4.86 \pm 0.00^{\mathrm{Cd}}$ & $4.70 \pm 0.01^{\mathrm{Ce}}$ & $4.62 \pm 0.00^{\mathrm{Cf}}$ & $4.61 \pm 0.01^{\mathrm{Bf}}$ \\
\hline
\end{tabular}

${ }^{1)} \mathrm{NM}$, squid 'Sikhae' made with glutinous foxtail millet; NB, squid 'Sikhae' made with glutinous barley; HM, squid 'Sikhae' made with glutinous foxtail millet by high hydrostatic pressure treatment; HB, squid 'Sikhae' made with glutinous barley by high hydrostatic pressure treatment.

${ }^{2)}$ Values are mean $\pm \mathrm{SD}(\mathrm{n}=3)$. ${ }^{\mathrm{A}-\mathrm{D}}$ Means in a column and ${ }^{\mathrm{a}-\mathrm{g}}$ means in a row followed by different superscripts are significantly different by Duncan's multiple range test respectively $(\mathrm{p}<0.05)$. 
Table 2. Changes in amino-N content (\%) of squid 'Sikhae' made with barley flour by high hydrostatic pressure treatment during storage at $10^{\circ} \mathrm{C}$

\begin{tabular}{cccccccc}
\hline & \multicolumn{5}{c}{ Storage period (day) } \\
\cline { 2 - 7 } Sample $^{1)}$ & 0 & 5 & 10 & 15 & 20 & 25 \\
\hline $\mathrm{NM}$ & $0.18 \pm 0.02^{\mathrm{Ac} 2)}$ & $0.19 \pm 0.02^{\mathrm{Ac}}$ & $0.26 \pm 0.01^{\mathrm{Ab}}$ & $0.36 \pm 0.01^{\mathrm{Ab}}$ & $0.39 \pm 0.01^{\mathrm{Aa}}$ & $0.40 \pm 0.01^{\mathrm{Aa}}$ & $0.41 \pm 0.01^{\mathrm{ABa}}$ \\
$\mathrm{NB}$ & $0.18 \pm 0.05^{\mathrm{Ae}}$ & $0.18 \pm 0.01^{\mathrm{Ae}}$ & $0.25 \pm 0.01^{\mathrm{ABd}}$ & $0.31 \pm 0.00^{\mathrm{Bc}}$ & $0.35 \pm 0.00^{\mathrm{Bc}}$ & $0.38 \pm 0.01^{\mathrm{Aab}}$ & $0.43 \pm 0.06^{\mathrm{Aa}}$ \\
$\mathrm{HM}$ & $0.16 \pm 0.02^{\mathrm{Ae}}$ & $0.19 \pm 0.02^{\mathrm{Ad}}$ & $0.23 \pm 0.02^{\mathrm{BCc}}$ & $0.29 \pm 0.02^{\mathrm{Bb}}$ & $0.28 \pm 0.01^{\mathrm{Db}}$ & $0.36 \pm 0.01^{\mathrm{Ba}}$ & $0.36 \pm 0.01^{\mathrm{Ba}}$ \\
$\mathrm{HB}$ & $0.16 \pm 0.01^{\mathrm{Ae}}$ & $0.21 \pm 0.02^{\mathrm{Ad}}$ & $0.22 \pm 0.02^{\mathrm{Cd}}$ & $0.27 \pm 0.01^{\mathrm{Cc}}$ & $0.32 \pm 0.01^{\mathrm{Cb}}$ & $0.35 \pm 0.01^{\mathrm{Ba}}$ & $0.36 \pm 0.00^{\mathrm{Ba}}$ \\
\hline
\end{tabular}

${ }^{1)} \mathrm{NM}$, squid 'Sikhae' made with glutinous foxtail millet; NB, squid 'Sikhae' made with glutinous barley; HM, squid Sikhae made with glutinous foxtail millet by high hydrostatic pressure treatment; HB, squid 'Sikhae' made with glutinous barley by high hydrostatic pressure treatment.

${ }^{1)}$ Values are mean $\pm \mathrm{SD}(\mathrm{n}=3)$. ${ }^{\text {A-D }}$ Means in a column and ${ }^{\mathrm{a}-\mathrm{e}}$ means in a row followed by different superscripts are significantly different by Duncan's multiple range test respectively $(\mathrm{p}<0.05)$.

는 증가하였으며, 아미노태 질소 함량은 초고압 처리 압력, 온도 및 시간 중 처리 온도에 의한 증가 효과가 컸다고 보고 하였다. Cho와 $\operatorname{Kim}(2012)$ 은 발효기간에 따른 오징어 식해의 아미노질소 함량은 $71-302 \mathrm{mg} \%$ 범위를 나타내었으며, $10^{\circ} \mathrm{C}$ 및 $20^{\circ} \mathrm{C}$ 에서는 아미노질소량이 지속적으로 증가하였다고 보 고하였다. Kim 등(1994a)은 오징어식해의 아미노태 질소 함 량은 $5^{\circ} \mathrm{C}, 10^{\circ} \mathrm{C}, 15^{\circ} \mathrm{C}$ 온도에서 숙성 15 일까지 급격하게 증가 하다가 그 이후로는 완만한 증가경향을 나타내었다고 보고하 였다.

휘발성 염기질소함량은 식품 단백질의 선도판정법으로 이 용되며, 수산발효식품의 품질 특성 중 선도를 판정하는 지표로 이용되고 있다(Cho와 Kim, 2012; Koo, 2015). 저장기간에 따 른 오징어 식해의 휘발성 염기질소 함량의 변화는 Table 3 과 같다. 모든 시료의 숙성 초기 휘발성 염기질소 함량은 10.73$14.00 \mathrm{mg} \%$ 로 나타났다. $\mathrm{NM}$ 및 $\mathrm{NB}$ 시료의 휘발성 염기질소 함량은 저장 10 일에 각각 $61.11 \mathrm{mg} \%$ 및 $60.18 \mathrm{mg} \%$ 를 나타내 었으며, 초고압 처리구의 경우 저장 15 일에 $\mathrm{HM}$ 및 $\mathrm{HB}$ 가 각각 $62.07 \mathrm{mg} \%$ 및 $62.05 \mathrm{mg} \%$ 를 나타내었다. 보리를 이용하여 제 조된 식해의 휘발성 염기질소 함량은 조를 이용하여 제조된 식
해의 함량과 비교할 때 저장 10 일부터 25 일까지 낮은 함량을 나타내었다. 또한, 보리를 이용하여 제조된 식해의 초고압 처 리구의 휘발성 염기질소 함량은 저장기간에 따라 초고압 무처 리구와 비교할 때 낮은 함량을 나타냈다. Jo와 $\operatorname{Kim}(2012)$ 은 오징어 식해의 휘발성 염기질소 함량은 식염의 농도가 낮고 발 효온도가 높을수록 함량이 급격히 증가하였다고 보고하였다. Han 등(2012)은 염장 및 당침 오징어를 이용하여 식염농도 $5 \%$ 및 $6 \%$ 로 제조된 오징어 식해의 휘발성 염기질소 함량은 $10^{\circ} \mathrm{C}$ 에서 숙성 10 일차에 31.70 및 $16.07 \mathrm{mg} / 100 \mathrm{~g}$ 을 나타낸다 고 보고하였으며, 시중에서 판매되는 가자미 및 명태 식해의 휘발성 염기질소 함량 및 염도는 전체적으로 오징어 식해에 비 해 높은 값을 나타내었다고 보고하였다. Jeong 등(2015)은 명 태식해의 휘발성 염기질소 함량은 $21^{\circ} \mathrm{C}$ 에서 숙성 10 일경에 $70.23 \mathrm{mg} / 100 \mathrm{~g}$ 까지 급격히 증가하였다고 보고하였다. 염도 를 달리하여 제조된 가자미 식해의 경우, 식염 $4 \%$ 함량인 가 자미 식해는 $10^{\circ} \mathrm{C}$ 에서 숙성 7-14일차에 휘발성 염기질소 함량 이 37.10-44.25 mg/100 g을 나타내었다고 보고하였다(Han 등, 2013). Ko 등(2017)은 젓갈의 휘발성 염기질소 함량의 증 가는 숙성 동안에 trimethylamine $N$-oxide(TMAO) 및 아미노

Table 3. Effect of high hydrostatic pressure treatment on volatile basic nitrogen contents (VBN, mg\%) of squid 'Sikhae' made with barley flour during storage at $10^{\circ} \mathrm{C}$

\begin{tabular}{cccccccc}
\hline \multirow{2}{*}{ Sample } & \multicolumn{5}{c}{ Storage period (day) } \\
\cline { 2 - 7 } & 0 & 5 & 10 & 15 & 20 & 25 & 30 \\
\hline NM & $13.07 \pm 0.81^{\mathrm{ABdl})}$ & $13.99 \pm 1.62^{\mathrm{Bd}}$ & $61.11 \pm 1.40^{\mathrm{Ac}}$ & $71.82 \pm 0.81^{\mathrm{Ab}}$ & $83.04 \pm 0.81^{\mathrm{Aa}}$ & $82.53 \pm 0.81^{\mathrm{Aa}}$ & $81.64 \pm 0.00^{\mathrm{Aa}}$ \\
$\mathrm{NB}$ & $12.13 \pm 0.00^{\mathrm{Be}}$ & $16.78 \pm 0.81^{\mathrm{Ae}}$ & $60.18 \pm 0.81^{\mathrm{Ad}}$ & $70.92 \pm 2.42^{\mathrm{Ac}}$ & $77.46 \pm 0.81^{\mathrm{Bb}}$ & $76.99 \pm 0.81^{\mathrm{Bb}}$ & $86.76 \pm 6.90^{\mathrm{Aa}}$ \\
$\mathrm{HM}$ & $14.00 \pm 0.81^{\mathrm{Ae}}$ & $13.53 \pm 0.81^{\mathrm{Be}}$ & $20.53 \pm 1.40^{\mathrm{Bd}}$ & $62.07 \pm 0.81^{\mathrm{Bc}}$ & $65.30 \pm 0.81^{\mathrm{Db}}$ & $64.85 \pm 0.81^{\mathrm{Db}}$ & $87.71 \pm 2.91^{\mathrm{Aa}}$ \\
$\mathrm{HB}$ & $10.73 \pm 0.00^{\mathrm{Cf}}$ & $13.99 \pm 0.81^{\mathrm{Be}}$ & $20.53 \pm 0.00^{\mathrm{Bd}}$ & $62.05 \pm 0.81^{\mathrm{Bc}}$ & $71.81 \pm 0.81^{\mathrm{Cb}}$ & $71.37 \pm 0.81^{\mathrm{Cb}}$ & $74.17 \pm 2.14^{\mathrm{Ba}}$ \\
\hline
\end{tabular}

${ }^{1)}$ Values are mean $\pm \mathrm{SD}(\mathrm{n}=3)$. ${ }^{\mathrm{A}-\mathrm{D}}$ Means in a column and ${ }^{\mathrm{a}-\mathrm{f}}$ means in a row followed by different superscripts are significantly different by Duncan's multiple range test respectively $(\mathrm{p}<0.05)$. 
산의 분해에 의한 암모니아의 생성과 trimethylamine(TMA) 및 dimethylamine(DMA) 등의 생성에 의한 것이라고 보고하 였다.

\section{색도 변화}

식품의 색도의 변화는 식품을 저장하거나 가공할 경우, 식 품에서 일어나는 현상으로 식품의 품질에 영향을 미친다 (Choi 등, 2017). 보리를 첨가하여 제조된 식해의 초고압 처 리에 의한 저장기간 중 색도의 변화는 Table 4 와 같다. NM, $\mathrm{NB}, \mathrm{HM}$ 및 $\mathrm{HB}$ 시료의 명도 $\left(\mathrm{L}^{*}\right)$ 는 각각 $38.14,40.40,39.12$ 및 42.13으로 나타났다. 보리를 이용하여 제조된 식해의 초 고압 처리구는 무처리구와 비교시 저장 5 일부터 25 일까지 명 도가 낮게 나타났으나, 저장 20 일 이후에는 두 시료간 명도는 유의적 차이를 보이지 않았다 $(\mathrm{p}>0.05)$. 오징어 식해의 적색 도(a*) 및 황색도(b*)의 경우는 모든 시료에서 저장 중 증가 하는 경향을 나타내었다. Kim 등(1993)은 오징어 조미젓갈 의 $\mathrm{L}$ 값의 경우 $10^{\circ} \mathrm{C}$ 에서 저장한 시료는 $20^{\circ} \mathrm{C}$ 및 $30^{\circ} \mathrm{C}$ 에서 저 장된 시료와 비교할 때 큰 변화를 나타내지 않았으며, a값의 경우 저장온도가 높을수록, 저장기간이 경과할수록 높게 나 타났다고 보고하였다.

\section{미생물수 변화}

보리를 첨가하여 제조된 식해의 초고압 처리에 의한 총균
수 및 젖산균수의 변화는 Fig. 1 및 Fig. 2와 같다. 조 및 보리 를 첨가하여 제조된 오징어 식해의 초기 총균수는 각각 6.17 및 $6.10 \log \mathrm{CFU} / \mathrm{g}$ 으로 나타났다. 저장 5 일에 $\mathrm{NM}$ 및 $\mathrm{NB}$ 의 총균수는 각각 8.24 및 $8.26 \log \mathrm{CFU} / \mathrm{g}$ 으로 증가하였으나 저 장 15 일에는 감소하는 경향을 나타내었다. $\mathrm{HM}$ 및 $\mathrm{HB}$ 의 총 균수는 저장 15 일에 각각 8.78 및 $8.32 \log \mathrm{CFU} / \mathrm{g}$ 을 나타났 으며, 초고압 처리된 오징어 식해의 경우, 저장 20 일에 총균 수가 감소하는 경향을 나타내었다. 초고압 처리에 의해 제조 된 오징어 식해의 총균수는 초고압 무처리구와 비교할 때 저 장 5 일차에 $2 \log$ cycle정도의 억제를 보이는 것으로 확인되 었다. $\operatorname{Lim}$ 등(2000)은 초고압 처리시 $200 \mathrm{MPa}$ 및 $300 \mathrm{MPa}$ 의 압력처리에 의해 멸치젓의 총균수는 감소하였다고 보고하 였다. Han 등(2012)은 염장 및 당침 처리된 오징어를 이용하 고, 식염농도를 각각 $5 \%$ 및 $6 \%$ 로 제조된 식해의 총균수는 $10^{\circ} \mathrm{C}$ 에서 저장 4 일째까지 $10^{7} \mathrm{CFU} / \mathrm{g}$ 이하를 나타냈다고 보 고하였다. 또한, Kim 등(1994b)은 오징어 식해의 총균수는 숙성 10 일만에 최대로 나타났으며, 숙성 15 일에 감소하였고, 숙성온도가 높을수록 많이 감소한다고 보고하였다.

식해의 저장기간에 따른 젖산균수 변화는 $\mathrm{NM}$ 시료를 제 외한 모든 시료에서 숙성 15 일에 최대균수를 나타내었다 (Fig. 2). $\mathrm{NM}$ 및 $\mathrm{NB}$ 의 경우, 저장 5 일 및 15 일에 각각 5.67, 7.82 및 $8.72,8.92 \log \mathrm{CFU} / \mathrm{g}$ 으로 나타났으며, 보리를 첨가 하여 제조된 식해의 젖산균수가 높은 것으로 확인되었다.

Table 4. Effect of high hydrostatic pressure treatment on color value of squid 'Sikhae' made with barley flour during storage at $10^{\circ} \mathrm{C}$

\begin{tabular}{|c|c|c|c|c|c|c|c|c|}
\hline \multirow{2}{*}{ Color values } & \multirow{2}{*}{ Sample } & \multicolumn{7}{|c|}{ Storage period (day) } \\
\hline & & 0 & 5 & 10 & 15 & 20 & 25 & 30 \\
\hline \multirow{4}{*}{$\mathrm{L}^{*}$} & $\mathrm{NM}$ & $38.14 \pm 0.70^{\mathrm{Cd} 1)}$ & $40.74 \pm 0.72^{\mathrm{Ac}}$ & $44.71 \pm 1.13^{\mathrm{Ab}}$ & $43.99 \pm 0.38^{\mathrm{BCb}}$ & $44.89 \pm 1.37^{\mathrm{Ab}}$ & $49.48 \pm 1.10^{\mathrm{Aa}}$ & $45.39 \pm 1.41^{\mathrm{Ab}}$ \\
\hline & NB & $40.40 \pm 0.83^{\mathrm{ABc}}$ & $40.78 \pm 0.65^{\mathrm{Ac}}$ & $44.81 \pm 1.09^{\mathrm{Ab}}$ & $45.72 \pm 0.37^{\mathrm{Ab}}$ & $44.91 \pm 0.79^{\mathrm{Ab}}$ & $49.73 \pm 0.99^{\mathrm{Aa}}$ & $44.73 \pm 0.54^{\mathrm{Ab}}$ \\
\hline & $\mathrm{HM}$ & $39.12 \pm 1.00^{\mathrm{BCe}}$ & $38.92 \pm 0.57^{\mathrm{Be}}$ & $41.17 \pm 0.69^{\mathrm{Bd}}$ & $43.43 \pm 0.92^{\mathrm{Cc}}$ & $44.38 \pm 0.32^{\mathrm{Abc}}$ & $49.63 \pm 0.60^{\mathrm{Aa}}$ & $45.15 \pm 0.44^{\mathrm{Ab}}$ \\
\hline & $\mathrm{HB}$ & $42.13 \pm 1.15^{\mathrm{Ac}}$ & $38.98 \pm 0.75^{\mathrm{Be}}$ & $40.30 \pm 0.65^{\mathrm{Bd}}$ & $44.98 \pm 0.68^{\mathrm{ABb}}$ & $44.78 \pm 0.07^{\mathrm{Ab}}$ & $48.90 \pm 0.57^{\mathrm{Aa}}$ & $45.24 \pm 0.68^{\mathrm{Ab}}$ \\
\hline \multirow{4}{*}{$a^{*}$} & NM & $29.04 \pm 0.82^{\mathrm{Ab}}$ & $28.39 \pm 0.71^{\mathrm{Bb}}$ & $28.95 \pm 1.62^{\mathrm{Bb}}$ & $32.25 \pm 0.42^{\mathrm{Ba}}$ & $32.29 \pm 1.26^{\mathrm{BCa}}$ & $29.76 \pm 1.43^{\mathrm{Cb}}$ & $33.05 \pm 1.56^{\mathrm{BCa}}$ \\
\hline & NB & $29.58 \pm 0.71^{\mathrm{Ad}}$ & $29.12 \pm 1.09^{\mathrm{Bd}}$ & $32.02 \pm 0.88^{\mathrm{Ac}}$ & $33.93 \pm 0.45^{\mathrm{Ab}}$ & $34.79 \pm 1.06^{\mathrm{Aab}}$ & $32.29 \pm 1.17^{\mathrm{Ac}}$ & $35.81 \pm 0.11^{\mathrm{Aa}}$ \\
\hline & $\mathrm{HM}$ & $29.57 \pm 0.70^{\mathrm{Acd}}$ & $29.75 \pm 0.35^{\mathrm{ABcd}}$ & $28.83 \pm 0.52^{\mathrm{Bd}}$ & $31.49 \pm 0.11^{\mathrm{Bb}}$ & $31.85 \pm 0.63^{\mathrm{Cab}}$ & $30.18 \pm 0.52^{\mathrm{BCc}}$ & $32.71 \pm 0.86^{\mathrm{Ca}}$ \\
\hline & $\mathrm{HB}$ & $30.12 \pm 1.14^{\mathrm{Ad}}$ & $30.57 \pm 0.59^{\text {Acd }}$ & $31.73 \pm 1.05^{\mathrm{Abc}}$ & $33.39 \pm 0.54^{\mathrm{Aa}}$ & $33.92 \pm 0.31^{\mathrm{ABa}}$ & $32.00 \pm 0.53^{\mathrm{ABb}}$ & $34.57 \pm 0.53^{\mathrm{ABa}}$ \\
\hline \multirow{4}{*}{$b^{*}$} & $\mathrm{NM}$ & $38.21 \pm 1.70^{\mathrm{Ab}}$ & $38.23 \pm 1.08^{\mathrm{Ab}}$ & $39.58 \pm 1.30^{\mathrm{ABab}}$ & $41.12 \pm 0.91^{\mathrm{Ba}}$ & $40.90 \pm 1.00^{\mathrm{Aa}}$ & $34.90 \pm 0.71^{\mathrm{Cc}}$ & $41.80 \pm 1.60^{\mathrm{Ca}}$ \\
\hline & NB & $37.50 \pm 1.62^{\mathrm{Ac}}$ & $36.03 \pm 1.02^{\mathrm{Bc}}$ & $39.12 \pm 1.47^{\mathrm{Bbc}}$ & $42.26 \pm 0.04^{\mathrm{Bab}}$ & $41.82 \pm 4.12^{\text {Aab }}$ & $38.79 \pm 1.19^{\mathrm{Abc}}$ & $44.77 \pm 0.96^{\mathrm{Aa}}$ \\
\hline & $\mathrm{HM}$ & $39.01 \pm 0.97^{\mathrm{Ac}}$ & $38.49 \pm 0.18^{\mathrm{Ac}}$ & $39.03 \pm 0.60^{\mathrm{Bc}}$ & $41.10 \pm 1.05^{\mathrm{Bb}}$ & $41.86 \pm 0.46^{\mathrm{Aab}}$ & $36.42 \pm 0.34^{\mathrm{Bd}}$ & $42.49 \pm 1.11^{\mathrm{BCa}}$ \\
\hline & $\mathrm{HB}$ & $38.86 \pm 3.09^{\mathrm{Ac}}$ & $38.81 \pm 0.58^{\mathrm{Ac}}$ & $41.63 \pm 0.80^{\mathrm{Ab}}$ & $44.16 \pm 0.74^{\mathrm{Aa}}$ & $42.63 \pm 0.83^{\mathrm{Aab}}$ & $36.57 \pm 0.67^{\mathrm{Bc}}$ & $44.35 \pm 0.43^{\mathrm{ABa}}$ \\
\hline
\end{tabular}

${ }^{1)}$ Values are mean $\pm \mathrm{SD}(\mathrm{n}=3) .{ }^{\mathrm{A}-\mathrm{C}}$ Means in a column and ${ }^{\text {a-e }}$ means in a row followed by different superscripts are significantly different by Duncan's multiple range test respectively $(\mathrm{p}<0.05)$. 


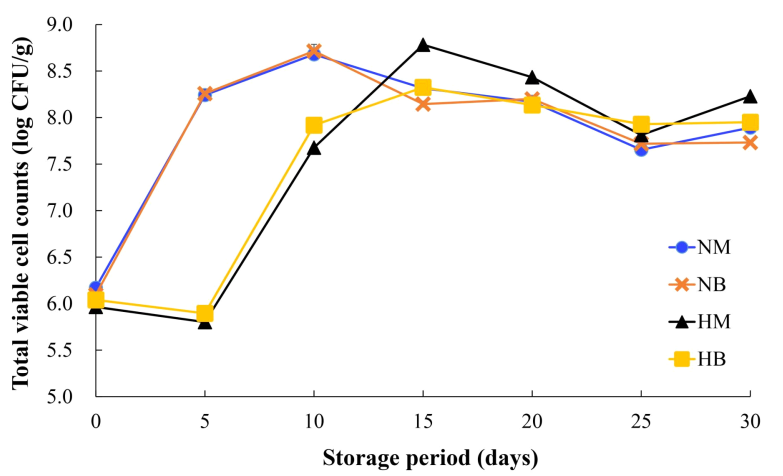

Fig. 1. Changes in total viable cell counts of squid 'Sikhae' made with barley flour by high pressure processing treatment during storage at $10^{\circ} \mathrm{C}$.

NM, squid 'Sikhae' made with glutinous foxtail millet; NB, squid 'Sikhae' made with glutinous barley; HM, squid 'Sikhae' made with glutinous foxtail millet by high hydrostatic pressure treatment; HB, squid 'Sikhae' made with glutinous barley by high hydrostatic pressure treatment.

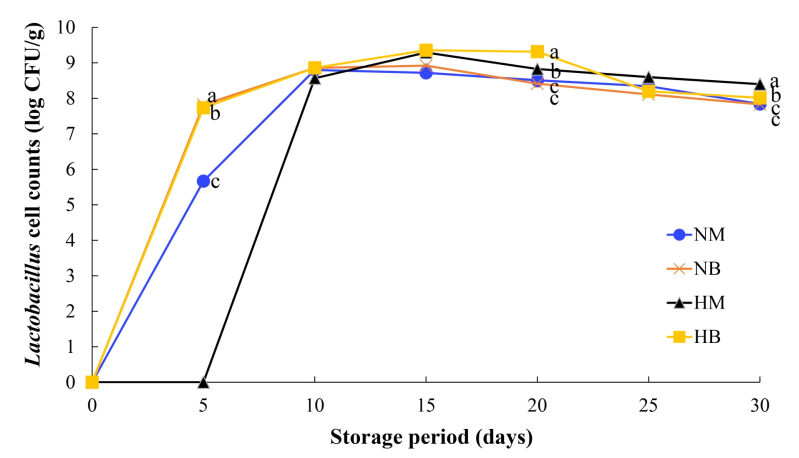

Fig. 2. Changes in Lactobacillus cell counts of squid 'Sikhae' made with barley flour by high pressure processing treatment during storage at $10^{\circ} \mathrm{C}$.

NM, squid 'Sikhae' made with glutinous foxtail millet; NB, squid 'Sikhae' made with glutinous barley; HM, squid 'Sikhae' made with glutinous foxtail millet by high hydrostatic pressure treatment; HB, squid 'Sikhae' made with glutinous barley by high hydrostatic pressure treatment.

${ }^{\mathrm{a}-\mathrm{c}}$ Means with different letters on graph are significantly different at $\mathrm{p}<0.05$ by Duncans multiple range test.

$\mathrm{HM}$ 및 $\mathrm{HB}$ 의 젖산균수는 저장 15 일에 각각 $9.29,9.36 \mathrm{log}$ $\mathrm{CFU} / \mathrm{g}$ 으로 가장 높게 나타났으며, 저장 20 일부터는 감소하 는 경향을 나타내었다. 본 연구에서 제조된 시료의 대장균군 은 검출되지 않았다. Lee 등(2015)은 통보리가루 $3 \%$ 를 첨가 하여 제조된 요구르트에서 유산균수는 저장 3 일차까지 증가 하다 그 이후로는 감소하였는데, 저장 12 일까지 유산균수는 $2.0 \times 10^{10} \mathrm{CFU} / \mathrm{mL}$ 수준을 유지하였다고 보고하였다. 또한, Han 등(2012)은 오징어 식해의 유산균수는 저장 온도별로 시료간 유의적 차이를 보였으며, 저장 $5^{\circ} \mathrm{C}$ 및 $10^{\circ} \mathrm{C}$ 저장온도
의 경우 숙성 9 일까지 급격히 상승하였다고 보고하였다. Kim 등(1994b)에 따르면 식해의 젖산균은 숙성 15 일에 최대 로 나타났으며, 그 후로는 감소하였고, 균수는 $10^{8}-10^{9} \log$ $\mathrm{CFU} / \mathrm{g}$ 이었다고 보고하였다. Souane 등(1987)은 가자미 식해 를 $5^{\circ} \mathrm{C}$ 및 $25^{\circ} \mathrm{C}$ 에서 발효할 경우 모두 Lactobacillus 및 Leuconostoc이 우점균으로 나타났다고 보고하였고, Lee 등 (1996)은 오징어 식해의 수분함량이 높을수록 젖산균수가 높 게 나타났다고 보고하였다.

\section{요 약}

본 연구에서는 곡류자원인 보리를 이용하여 저염 수산발 효식품인 식해를 제조하였고, 초고압처리한 후 식해의 저장 기간에 따른 품질 변화를 확인하였다. 보리를 이용하여 제조 된 식해의 경우, 저장기간에 따라 조를 이용하여 제조된 식해 와 비교할 때 $\mathrm{pH}$, 아미노질소, 휘발성 염기질소 함량 및 미생 물수 변화에 대해 저장기간에 따른 차이를 나타내었으며, 초 고압 처리에 의한 영향도 확인되었다. 보리를 이용하여 제조 된 식해의 $\mathrm{pH}$ 및 아미노질소 함량은 6.77 및 $0.18 \%$ 를 나타 냈으며, 저장 15 일에는 그 함량이 각각 4.79 및 $0.31 \%$ 를 나 타내었다. 보리를 첨가하여 제조된 식해의 휘발성 염기질소 함량은 저장 10 일에 초고압 처리구 및 초고압 무처리구는 각 각 $20.53 \mathrm{mg} \%$ 및 $60.18 \mathrm{mg}$ \%를 나타내었다. 그러나 보리를 첨가하여 초고압 처리한 식해의 휘발성 염기질소 함량은 저 장 15 일에 $62.05 \mathrm{mg} \%$ 를 나타내어 증가하는 경향을 나타내 었다. 식해의 저장기간에 따른 색도의 변화를 확인한 결과, 명도는 저장 25 일까지 보리를 이용한 식해가 조를 이용한 식 해보다 높은 값을 나타내었다. 저장기간에 따른 오징어 식해 의 총균수의 경우, 보리를 이용하여 제조된 식해의 초고압 무 처리 시료는 저장 5 일에 $8.26 \log \mathrm{CFU} / \mathrm{g}$ 을 나타내었으나, 초 고압 처리구의 경우 저장 10 일에 $7.92 \log \mathrm{CFU} / \mathrm{g}$ 을 나타내었 다. 저장기간에 따른 젖산균수의 변화는 보리를 첨가하여 제 조된 식해의 초고압 처리구는 저장 15 일에 $9.36 \log \mathrm{CFU} / \mathrm{g}$ 으 로 가장 높은 값을 나타내었다. 따라서 곡류자원으로 보리를 이용한 저염 수산발효식품인 식해를 제조하고, 식해의 초고 압 처리는 저장기간에 따른 품질 변화에 긍정적인 영향을 주 는 것으로 확인되었다.

\section{Conflict of interests}

The authors declare no potential conflict of interest.

\section{ORCID}

Jae Hun Yang https://orcid.org/0000-0002-7580-7090 
Na-Young Lee https://orcid.org/0000-0002-0225-4800

\section{References}

Ames NP, Rhymer CR. Issues surrounding health claims for barley. J Nutr, 138, 1237S-1243S (2008)

Baik BK, Ullrich SE. Barley for food: Characteristics, improvement, and renewed interest. J Cereal Sci, 48, 233-242 (2008)

Cho WI, Kim SM. The biofunctional activities and shelf-life of low-salt squid Sikhae. Korean J Food Sci Technol, 44, 61-68 (2012)

Choi KH, Kim SI, Lee DU, Jeon JT. Effect of shelf-life extension of birch sap using high pressure processing. Korean J Food Preserv, 24, 343-350 (2017)

Han DW, Han HJ, Kim DG, Im MJ, Cho SY. Optimal fermentation conditions (temperature and salt concentration) for preparing flounder Verasper moseri Jordan et Gilberu Sikhae. Korean J Fish Aquat Sci, 46, 689-695 (2013)

Han DW, Kim SR, Im MJ, Cho SY. Optimal processing conditions of fermentation temperature and sea salt concentration for preparing squid Todarodes paxificus Sikhae. Korean J Fish Aquat Sci, 45, 627-634 (2012)

Jeong EJ, Kim H, Cha YJ. Quality of Alaska pollack Theragra chalcogramma Sikhae after fermentation for different times. Korean J Fish Aquat Sci, 48, 293-300 (2015)

Jeong YS, Kima JW, Lee ES, Han YY, Gil NY, Lee MJ, Lee GH, Hong ST. Studies on physico-chemical characterization of starch extracted from domestic barley cultivars. Food Eng Prog, 17, 203-211 (2013)

Kim DS, Kim YM, Koo JG, Lee YC, Do JR. A study on shelf-life of seasoned and fermented squid. Korean J Fish Aquat Sci, 26, 13-20 (1993)

Kim JH, Kim MJ, Lee JS, Kim KH, Kim HJ, Heu MS, Kim JS. Development and characterization of sea squirt Halocynthia roretzi Sikhae. Korean J Fish Aquat Sci, 46, 27-36 (2013)

Kim JS, Heu MS, Kim HS, Ha JH. Basic and Application of Fishery Processing Engineering. Hyoilbook Co, Seoul, Korea, p 251-274 (2007)

Kim SM, Jeong IH, Cho YJ. The development of squid (Todarodes pacificus) Sikhae in Kang-Nung district, 1.
The effects of fermentation temperatures and periods on the properties of squid Sikhae. Korean J Fish Aquat Sci, 27, 215-222 (1994a)

Kim SM, Cho YJ, Lee KT. The development of squid (Todarodes pacificus) Sikhae in Kang-Nung district, 2. The effects of fermentation temperatures and periods on chemical and microbial changes, and the partial purification of protease. Korean J Fish Aquat Sci, 27, 223-231 (1994b)

Kim SM, Bank OD, Lee KT. The development of squid (Todarodes pacificus) Sikhae in Kang-Nung district, 3. The effects of garlic concentrations on the properties of Sikhae. Korean J Fish Aquat Sci, 27, 357-365 (1994c) Kim SM, Bank OD, Lee KT. The development of squid (Todarodes pacificus) Sikhae in Kang-Nung district, 4. The effects of red pepper and grain contents on the properties of squid Sikhae. Korean J Fish Aquat Sci, 27, 366-372 (1994d)

Kim SR, Han DW, Im MJ, Cho SY. Optimal processing conditions and concentrations for red pepper powder and crushed garlic in the manufacture of squid Todarodes paxificus Sikhae. Korean J Fish Aquat Sci, 45, 640-647 (2012)

Ko YA, Kim SH, Song HS. Effect of salt concentration and fermentation temperature on changes in quality index of salted and fermented anchovy during fermentation. J Food Hyg Saf, 32, 27-34 (2017)

Koo JG. Food Chemistry Experiment Method. Bioscience Publishing. Seoul, Korea, p 107-110 (2015)

Koo SY, Cha KH, Lee DU. Effects of high hydrostatic pressure on foods and biological system. Food Science and Industry, 40, 23-30 (2007)

Korea Food and Drug Administration (KFDA). Food Code. Korea Food and Drug Administration, Seoul, Korea, $p$ 294-295 (2018)

Lee CH. Fish fermentation technology. Kor J Appl Microbiol Bioeng, 17, 645-654 (1989)

Lee $\mathrm{CH}$. Lactic acid fermented foods and their benefits in Asia. Food Control, 8, 259-269 (1997)

Lee MJ, Kim YK, Kim KH, Lee NY. Quality characteristics of whole barley flour added to yogurt during storage. Food Eng Prog, 19, 8-13 (2015)

Lee NH, Oh SW, Kim YM. Biochemical changes in muscle protein of squid Sikhae during fermentation: Effects of 
temperature and moisture content. Korean J Food Sci Technol, 28, 292-297 (1996)

Lee SB, Uhm BH, Yoon WB. Effect of high pressure processing on the rancidity of Yeonhaeju soybean (Bazaz) powder during storage. Food Eng Porg, 15, 209-213 (2011)

Lim SB, Yang MS, Kim SH, Mok C, Woo GJ. Changes in quality of low salt fermented anchovy by high hydrostatic pressure treatment. Korean J Food Sci Technol, 32, 111-116 (2000)

Martinez M, Motilva MJ, de las Hazas MCL, Romero MP, Vaculova K, Ludwig IA. Phytochemical composition and $\beta$-glucan conetnet of barley genotypes from two different geographic origins for human health food production. Food Chem, 245, 61-70 (2018)

Park JY, Na SY, Lee YJ. Present and future of non-thermal food processing technology. Food Science and Industry, 43, 2-20 (2010)

Park JY. Study on the shelf-life extension of squid Sikhae. MS Thesis, Kunsan National University, Korea, p 3-6 (2012)
Park WJ, Lee SH, Lee H. Antibacterial and proteolytic activities of bacterial isolates from ethnic fermented seafoods in the east coast of Korea. Food Eng Prog, 21, 88-92 (2017)

Pejcz E, Czaja A, Wojciechowicz-Budzisz A, Gil Z, Spychaj R. The potential of naked barley sourdough to improve the quality and dietary fibre content of barley enriched wheat bread. J Cereal Sci, 77, 97-101 (2017)

Rendueles E, Omer MK, Alvseike O, Alonso-Calleja C, Capita R, Prieto M. Microbiological food safety assessment of high hydrostatic pressure processing: A review. LWT-Food Sci Technol, 44, 1251-1260 (2011)

Sharma P, Gujral HS. Antioxidant and polyphenol oxidase activity of germinated barley and its milling fractions. Food Chem, 120, 673-678 (2010)

Souane M, Kim YB, Lee CH. Microbial characterization of gajami Sikhae fermentation. Kor J Appl Microbiol Bioeng, 15, 150-157 (1987)

Suh HK. A study on the regional characteristics of Korean Chotkal: The ways of preservation of Chotkal. J Korean Soc Food Cult, 2, 149-161 (1987) 